\title{
Vertical Integration of HRD Policy within Companies.
}

\author{
A.A.M. (Ida) Wognum \\ University of Twente, Enschede, The Netherlands
}

\begin{abstract}
This study concerns HRD policymaking in companies. More specifically it explores whether so-called vertical integration of HRD policy at different organizational levels occurs within companies. Findings indicate a virtual absence of HRD policymaking or strategic HRD aligning, in all aspects and levels within the companies studied. It is thus problematical to harmonize HRD policy processes in a vertical direction.
\end{abstract}

Keywords: HRD Policy, Policy Integration, Policy Harmonization

The survey reported here is part of the Strategic Human Resource Development (HRD) project in which the effects of strategic HRD are studied within companies. Strategic HRD refers to the planned learning and development of individual and groups of employees for the benefit of the company as well as themselves (e.g. Garavan, Costine and Heraty, 1995). Central to this is that HRD programs have to be aligned to the company concerned. HRD policymaking is the process in which strategic choices are made concerning these targeted programs and other learning activites. It is an interactive process whereby as part of ongoing and future company policy, appropriate HRD goals and objectives are formulated regarding employees' and company development (Wognum, 1999). Theoretically, optimal HRD policymaking should take place at strategic, tactical, and operational levels within organizations, with relevant stakeholders involved at every level. Theories based on the systems approach often plead for a harmonization of HRD policy at various levels of the organization (Gilbert, 1978; Van de Ven \& Drazin, 1985; Banathy, 1991; Romiszowski, 1984; Rummler \& Brache, 1990; Swanson, 1994). When this does not happen, it is highly likely that HRD programs will be ineffective. It is therefore interesting to explore whether vertical integration of HRD policy at different organizational levels actually occurs within companies.

\section{Theoretical Framework}

Organizational problems and development and their related training needs may occur at the strategic, tactical and operational levels of the organization (Figure 1). Optimal HRD policymaking (Figure 1) should take place at these three levels (Rothwell \& Kazenas, 1989) in order to align HRD programs strategically to the company concerned. HRD policymaking, therefore, includes information gathering and identification of potential HRD needs at each company level in cooperation with the relevant stakeholders. These needs relate to performance levels and business results stakeholders are striving towards. HRD policymaking at the strategic level, with a company's top management as primary stakeholder, includes analyzing corporate mission, strategy, problems, developments and other issues which, at this level, may serve as starting point for HRD processes. HRD policymaking at the tactical level, with middle managers as primary stakeholders, includes analyzing problems and development around the coordination and cooperation between organizational departments which may call for HRD interventions. HRD policymaking at operational level, with lower executive management and other employees in the operating core as primary stakeholders, includes identifying performance problems of individual workers and operational departments (Tjepkema \& Wognum, 1999). HRD policymaking at these three levels is thus an interactive process whereby as part of an ongoing and future company policy, appropriate HRD goals and objectives are formulated concerning targeted programs and other learning activites so that employees acquire the competencies necessary to improve performance and organizational effectiveness.(Torraco, 1995).

The HRD function, which is usually in the form of an HRD department, also comprises three levels: HRD policymaking at strategic level; HRD administration at tactical level; and HRD implementation at operational level (Figure 1). HRD policymaking is already described in the above section. HRD administration concerns the process of creating favorable conditions for implementing the stated goals and objectives. It includes the allocation of HRD staff, budgets and other resources. HRD implementation concerns the effective implementation of learning processes

\section{3}


and includes decisions on specific HRD activities like selecting employees to be trained or educated, time schedules and other detailed arrangements.

\begin{tabular}{|c|c|}
\hline \multicolumn{1}{|c|}{ HRD function } & Company \\
\hline HRD policymaking & Strategic \\
\hline HRD administration & Tactical \\
\hline HRD implementation & Operational \\
\hline
\end{tabular}

Figure 1: Levels in HRD policymaking

\section{Strategic Partnership and Vertical Integration}

By means of the lines between HRD policymaking and the three company levels (see Figure 1) it is envisaged that optimal HRD policymaking takes place at strategic, tactical, and operational levels within the organization. Cooperation between allthose involved - top, middle and lower executive management, employees in the operating core, and $\mathrm{HRD}$ company representatives - is necessary in order to arrive at strategically aligned $\mathrm{HRD}$ programs and other learning interventions. This so-called 'strategic partnership' (Kaufman, 1986; Robinson \& Robinson, 1989) leads to more commitment, and a positive attitude of stakeholders towards training and development.

Though often worded in different ways, virtually all systems theorists opt for mutual tuning and harmonization between decisionmaking at strategic, tactical and operational levels (Gilbert, 1978; Van de Ven \& Drazin, 1985; Banathy, 1991; Romiszowski, 1984; Rummler \& Brache, 1990; Swanson, 1994). Decisionmaking at strategic level has to be translated into tactical and operational levels (and vice versa) in order to achieve an integrated and coherent HRD company policy. Because of the more or less hierarchical levels, this harmonization between strategic, tactical and operational policy processes is called 'vertical integration of HRD policy'. When this integration does not take place, it is highly likely that HRD programs will be ineffective (cf. Van de Ven \& Drazin, 1985). Earlier empirical reserach has established that a true integration of policy processes at these levels is extremely limited within companies (Mulder, Akkerman \& Bentvelsen, 1989; Wognum, 1998). It is therefore interesting to explore further whether this so-called vertical integration of HRD policy at different organizational levels occurs within companies.

\section{HRD Policymaking and Strategic HRD Aligning}

In policymaking practices all kinds of accidental and unplanned working procedures take place, which also determine the way policymaking processes occur (Mintzberg, 1994). In order to study the vertical integration of HRD policy processes in companies, this study therefore departs from the actual performed HRD policymaking processes, identified by the term 'strategic HRD aligning'. The word 'strategic' emphasizes the company perspective and connects the link between HRD and organizational goals and objectives. Strategic aligning thus concerns the development of HRD goals and objectives and HRD interventions which are aligned with company strategy, problems, and developments at all company levels. The aligning process consists of three stages: 1. Identifying organizational strategies, problems and developments at all company levels; 2. Examining these in relation to possible HRD implications; 3. Making strategic choices about the way in which strategies, problems and developments can be supported by HRD programs and other learning activities. Based on the foregoing and also on features of decisionmaking models (Koopman \& Pool, 1992; Van Heffen, 1993), strategic HRD aligning is characterized by four aspects: participation, information, formalization, and decisionmaking. Participation means the involvement of participants, the so-called HRD stakeholders, at various company levels in the aligning process. Information refers to the data needed to gain more insight into the problem and related HRD needs. Data from various organizational levels are needed to decide which HRD goals and objectives are important in order to align HRD programs to the company. Formalization refers to the formal consultative structure and information gathering procedures of the aligning process. Decision-making is about making choices regarding the supporting of problems and developments in the company by HRD programs and other learning interventions. It is concerned with 
determining the appropriate HRD goals and objectives at various organizational levels, target groups and content of HRD programs and other learning interventions.

\section{Research Question}

In this study an important question is whether optimal HRD policymaking at strategic, tactical, and operational level of an organization has taken place. The study focuses specifically on the harmonization of HRD policy at these company levels - the so-called vertical integration of HRD policy. The main research question is then: to what extent will vertical integration of HRD policy in companies occur? Because this study departs from actual performed HRD policymaking processes, the main focus is on the vertical integration of strategic HRD aligning.

\section{Methods}

The survey reported here was carried out as part of a larger one among Dutch companies. Large companies (more than 500 employees) from the industrial sector and the financial and commercial services sector were selected from a national database from the Association of Chambers of Commerce. Research has shown that in absolute terms the greatest effort in HRD programmes is made in companies of this size and within these specific sectors (Mulder, Akkerman \& Bentvelsen, 1989). The present study started from a group of 44 companies already studied earlier in the main research project (Wognum, 1999). A non-response analysis showed no significant differences between the non-response group and the 44 companies in the study concerning certain contextual variables such as size and structure of the company and structure and position of the HRD function.

Sample. In order to answer the research question, a survey was carried out among 44 Dutch companies with more then 500 employees in two economic sectors ( 11 from the industrial sector and 33 from the financial and commercial services sector). In each of these organizations one HRD program was selected from two frequently recurring areas of HRD activities, namely automation and social skills. These areas were selected for two reasons. Firstly, both types of HRD program were offered in the 44 companies. Secondly, earlier research findings indicate some differences in the level of contentment of employees with the aligning procedures. In companies where social skills programs were offered respondents were more discontented about the aligning procedure than in companies that did not give this kind of training. No significant differences were found in the case of automation programs (Wognum, 1998). The selection process resulted in 23 automation and 21 social skills programs. Four categories of respondents were selected: the HRD company representative, a maximum of $15 \mathrm{HRD}$ participants in the selected programs, their supervising manager and (if present) their subordinates. All groups can be considered as having an interest in HRD policymaking in companies (the so-called groups of stakeholders).

Data collection. Data were collected in the spring and summer of 1997 using a questionnaire sent to 767 representatives of the four groups of stakeholders (44 HRD company representatives, 357 HRD participants, 242 of their supervising managers and 124 of their subordinates). The questionnaire was designed to collect information on the aforementioned process of strategic HRD aligning, and comprised mainly precoded questions with some open answers intended for additionel comments. Questions concerned respondents' participation in the aligning process, information they had provided (ten categories were identified, including company's strategy and performance results, operating procedures of the unit or department the respondents worked for, and respondents' knowledge, skills and attitudes), the consultative structures and information gathering procedures applied (including formal as well as informal meetings, projects, and evaluation procedures), and the kind and level of determined HRD goals and objectives (including respondents' knowledge, skills, attitudes, working behavior, and performance results at the operational level, the performance results of their unit or department at tactical level, and the performance results of the entire company at strategic level).

Response. 752 questionnaires were sent to the automation group (23 HRD company representatives, 320 trainees, 277 managers, and 132 subordinates). All $23 \mathrm{HRD}$ company representatives completed the questionnaire, while $54 \%$ of trainees, $43 \%$ of managers, and $29 \%$ of subordinates responded. 740 questionnaires were sent to the 'social skills' group (21 HRD company representatives, 292 trainees, 251 managers, and 176 subordinates). All HRD representatives completed the questionnaire, while $63 \%$ of trainees, $49 \%$ of managers, $49 \%$ of subordinates responded. The final group of respondents in this study had a sample size of $44 \mathrm{HRD}$ company representatives, 357 HRD participants, 242 supervising managers and 124 subordinates.

Analysis. The two-staged sampling design used (first a sample of companies, then a sample of respondents within each company) resulted in a hierarchical, nested data structure. To arrive at answers to the research question, therefore, not only descriptive statistics but also multilevel analysis was used. Multilevel statistical models (cf.

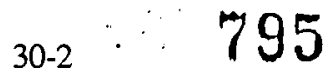


Goldstein, Rasbach, Plewis, et all, 1998) are suitable for handling data with such a hierarchical structure. These models allowed us to make statistical inferences both at individual respondent (sample size 767) and company size (sample size 44) levels. It shouls also be noticed that multilevel analysis includes the estimation of expected means. Results

Strategic aligning concerns the development of HRD goals and objectives and HRD interventions, which are aligned with company strategy, problems, and developments at all company levels. As was described before, it represents the actual performed HRD policymaking process within the companies studied, and is characterized by four aspects; participation, information, formalization and decision-making.

\section{Participation}

From the data in Tabel 2 it may be concluded that the four groups of respondents were involved, on average, in less than one of two stages of the aligning process. The first stage of identifying organizational strategies, problems and developments at all company levels was not involved in the analysis since this was not required of three of the four respondent groups. Supervising managers were the most involved participants ( $M=.99$ ), while subordinates were the least involved $(M=.26)$. Three groups of respondents, however, attached great interest to their participation in aligning processes (HRD representatives were not questioned in this perspective). The mean score of HRD participants on a five-point scale is $3.87(\mathrm{SD}=.86)$, supervising managers 4.01 ( $\mathrm{SD}=.69$ ), and subordinates $3.59(\mathrm{SD}=.93)$ (Table 1).

Table 1: Means and standard deviations per group of respondents concerning the importance attached to participation and the providing of information in strategic HRD aligning

\begin{tabular}{lrrrrrr}
\hline & \multicolumn{2}{c}{$\mathrm{P}^{\mathrm{a})}$} & \multicolumn{2}{c}{$\mathrm{M}^{\mathrm{b})}$} & \multicolumn{3}{c}{$\mathrm{S}^{\mathrm{c})}$} \\
\cline { 2 - 7 } & $\mathrm{M}$ & $\mathrm{SD}$ & $\mathrm{M}$ & $\mathrm{SD}$ & $\mathrm{M}$ & $\mathrm{SD}$ \\
\hline importance of participartion $^{\mathrm{d})}$ & 3.87 & .86 & 4.01 & .69 & 3.59 & .93 \\
importance of provinding information $^{\mathrm{d})}$ & 3.84 & .86 & 4.03 & .72 & 3.63 & .92 \\
\hline
\end{tabular}

$\begin{array}{ll}\text { a) } & \text { P: Participant of HRD programs ( } N=357) \\ \text { b) } & \text { M: Supervising manager of HRD participant }(\mathrm{N}=242) \\ \text { c) } & \text { S: Subordinate of HRD participant }(\mathrm{N}=124) \\ \text { d) } & \text { Scale running from } 1 \text { (totally unimportant) to } 5 \text { (very important) }\end{array}$

\section{Information}

This aspect of the aligning process concerns the information needed to gain more insight into the problem and related HRD needs. The data presented in Table 2 indicate that HRD participants, their supervising managers and subordinates attach great interest to providing information (HRD representatives were not questioned in this perspective). The mean scoreof HRD participants on a five-point scale is $3.84(\mathrm{SD}=.86)$, supervising managers 4.03 $(\mathrm{SD}=.7269)$, and subordinates $3.63(\mathrm{SD}=.92)$ (Table 1). It turned out, however, that their interests are insufficiently converted into a real provision of information. With the exception of HRD representatives, respondents provided information, on average, on less than one information category out of ten, concerning less than one of the three distinguished policy levels (see Table 2). Table 3 visualizes that this has to be the operational level, where $81.8 \%$ of HRD company representatives, $23 \%$ of HRD participants, $28.2 \%$ of their supervising managers, and $4.0 \%$ of their subordinates provided information mainly on the knowledge, skills and attitudes of the participants in the selected HRD programs 
Table 2: Strategic HRD aligning in companies: means per group of respondent, and level of agreement between groups of respondents and between respondents within companies

\begin{tabular}{|c|c|c|c|c|c|c|}
\hline & $\mathrm{N}$ & $P^{\text {a) }}$ & $\mathrm{M}^{\mathrm{b})}$ & $S^{c)}$ & $\mathrm{H}^{\mathrm{d})}$ & $\begin{array}{l}\text { agreement } \\
\text { within } \\
\text { companies }\end{array}$ \\
\hline $\begin{array}{l}\text { number of stages in which was } \\
\text { participated (maximum }=2)\end{array}$ & 767 & .62 & $.99^{* *}$ & $26^{* *}$ & .64 & .15 \\
\hline $\begin{array}{l}\text { number of categories of provided } \\
\text { information (maximum }=10 \text { ) }\end{array}$ & 767 & .58 & $.88^{* *}$ & $.25^{* *}$ & $4.13^{* *}$ & .09 \\
\hline $\begin{array}{l}\text { number of policy levels of provided } \\
\text { information (maximum }=3 \text { ) }\end{array}$ & 767 & .45 & $.67^{* *}$ & $.18^{\circ *}$ & $2.30^{\circ *}$ & .08 \\
\hline $\begin{array}{l}\text { number of consultative structures in } \\
\text { which involved (maximum }=4)\end{array}$ & 767 & .50 & $.66^{* *}$ & $.35^{* *}$ & $1.30^{* *}$ & .07 \\
\hline $\begin{array}{l}\text { number of information gathering } \\
\text { procedures applied (maximum }=7 \text { ) }\end{array}$ & 723 & .63 & $.88^{* *}$ & $.34^{\circ \cdot}$ & $x$ & .10 \\
\hline $\begin{array}{l}\text { number of types of HRD goals and } \\
\text { objectives formulated (maximum }=6 \text { ) }\end{array}$ & 767 & 1.01 & $1.18^{\circ \bullet}$ & .92 & $1.77^{* *}$ & .02 \\
\hline $\begin{array}{l}\text { number of policy levels of HRD goals } \\
\text { and objectives formulated (max }=3 \text { ) }\end{array}$ & 767 & .89 & $1.01^{* *}$ & $.80^{*}$ & $1.11^{* *}$ & .03 \\
\hline $\begin{array}{l}\text { number of aligning aspects } \\
(\text { maximum }=4)\end{array}$ & 767 & 2.06 & $2.64^{*}$ & $1.54^{* *}$ & $3.34^{\circ \bullet}$ & .14 \\
\hline $\begin{array}{l}\text { number of aligning levels } \\
(\text { maximum }=3)\end{array}$ & 767 & .79 & $.94^{\circ *}$ & $.62^{\circ}$ & $1.73^{* *}$ & .08 \\
\hline
\end{tabular}

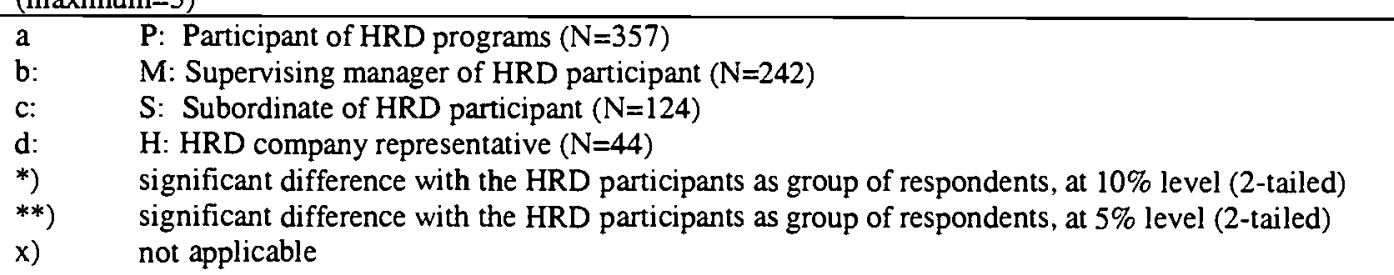

\section{Formalization}

Formalization refers to the formal consultative structure and information gathering procedures of the aligning proces. Scant participation in formal or informal consultative structures was found and minor use made of information gathering procedures. The data in Table 2 indicate that HRD specialists, on average, participated in 1.30 of 4 consultative structures (formal and regular meetings as well as temporary or informal or other kind of consultative structures). The scores for the other groups of respondents are even lower (.50 on average for HRD participants, .66 for supervising managers, and .35 for subordinates). It also turned out that, on average, less than one of the seven procedures of information gathering (i.e. tests and other evaluation procedures, environmental scanning, analysis of documents like policy plans, and more informal ways of information gathering) were utilized by groups of respondents.

Table 3: Percentages per respondent group of providing information per policy level

\begin{tabular}{lrrrr}
\hline org. level of providing information & $\mathrm{H}^{\mathrm{a}}$ & $\mathrm{P}^{\mathrm{b})}$ & $\mathrm{M}^{\mathrm{c})}$ & $\mathrm{S}^{\mathrm{d}}$ \\
\hline strategic & 79,5 & 6.4 & 18.2 & 3.2 \\
tactical & 68,2 & 16.5 & 19.1 & 13.7 \\
operational & 81.8 & 23.0 & 28.2 & 4.0 \\
\hline
\end{tabular}
a) $\mathrm{H}$ : HRD company representative $(\mathrm{N}=44)$
b) P: Participant of HRD programs $(\mathrm{N}=357)$
c) M: Supervising manager of HRD participant $(\mathrm{N}=242)$
d) S: Subordinate of HRD participant $(N=124)$ 


\section{Decisionmaking}

Decisionmaking is about making choices regarding the supporting of problems and developments in the company by using HRD programs and other learning interventions. This survey focused on the HRD goals and objectives of the selected HRD programs in the areas of automation and social skills. It proved that, on average, HRD goals and objective were formulated at one out of three company levels ( $M=1.11$ for HRD company representatives, $M=1.01$ for supervising managers, $M=.89$ for $H R D$ participants, and .80 for the subordinates). It mainly concerns the operational level including the learning goals, working behavior and performance results of individual employees. Data in Table 4 indicate that more than $70 \%$ of HRD specialists, $68 \%$ of HRD participants, $66 \%$ of supervising managers, and $54 \%$ of subordinates point to the formulation of goals at this operational level, concerning the knowledge, skills and attitudes of individual employees. The percentages of the other operational level goals are considerably lower. There are hardly any goals formulated at strategic and tactical company levels.

Table 4: Percentages of respondents for decisionmaking in strategic HRD aligning (multiple response)

\begin{tabular}{|c|c|c|c|c|}
\hline goals and objectives to achieve & $\mathrm{H}^{2)}$ & $P^{\text {b) }}$ & $\mathrm{M}^{\mathrm{c})}$ & $S^{\text {d) }}$ \\
\hline no specific goals and objectives & 11,4 & 9,2 & 2,9 & 6,3 \\
\hline $\begin{array}{l}\text { at strategic level } \\
\text { performance results of the company some time after end of program }\end{array}$ & 6,8 & 3,8 & 7,1 & 5,3 \\
\hline $\begin{array}{l}\text { at tactical level } \\
\text { performance results of the department some time after end of program }\end{array}$ & 18,2 & 12,4 & 15,1 & 20,4 \\
\hline $\begin{array}{l}\text { at operational level } \\
\text { knowledge, skills and atitudes at the end of the program } \\
\text { working behavior at the end of the program } \\
\text { performance results of individual employees }\end{array}$ & $\begin{array}{l}70,5 \\
47,7 \\
27,3\end{array}$ & $\begin{array}{r}67,9 \\
6,6 \\
7,8\end{array}$ & $\begin{array}{l}66,4 \\
13,0 \\
13,9\end{array}$ & $\begin{array}{r}54,0 \\
7,1 \\
5,3\end{array}$ \\
\hline $\begin{array}{l}\text { other } \\
\text { other kind of goals and objectives }\end{array}$ & 6.8 & 5,8 & 4,6 & 9,7 \\
\hline
\end{tabular}

a) H: HRD company representative $(\mathrm{N}=44)$

b) P: Participant of HRD programs $(\mathrm{N}=346)$

c) M: Supervising manager of HRD participant $(\mathrm{N}=238)$

d) S: Subordinate of HRD participant $(\mathrm{N}=113)$

\section{Strategic HRD Aligning: Aligning Aspects and Aligning Levels}

So far, the results of the four separate aspects of strategic HRD aligning, participation, information, formalization, and decisionmaking, have been presented. In order to gain an overall insight into the actual HRD aligning processes within the companies studied, two new variables were constructed. The first 'aligning aspects' indicates the number of aspects in which respondents were involved. The second 'aligning levels' indicates the number of policy levels (strategic, tactical and operational) that were included into the aligning process. The findings, also represented in Table 2, indicate a virtual absence of strategic $\mathrm{HRD}$ aligning in all aspects and levels in the companies studied. HRD company representatives were involved in most aspects $(M=3.34)$ and aligning levels $(M=1.73)$, while other groups of respondentswere less involved, on average, in all aspects and levels of strategic aligning.

\section{Strategic Partnership}

In the foregoing sections many differences between the groups of respondents were found concerning their involvement in the four aspects and three levels of strategic HRD aligning. More insight into these differences is needed in order to draw a conclusion at the level of strategic partnership. Tabel 2 presents the results of the analysis indicating that the scores of supervising managers, subordinates and HRD company representatives significantly differ in many ways from those of HRD participants. Supervising managers, for instance, were involved in more stages of the aligning process, provided information on more categories and policy levels, formulated more kinds of goals and objectives than did HRD participants.

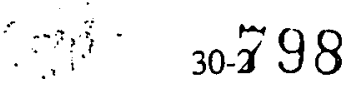


The intraclass correlation coefficient (Bryk \& Raudenbusch, 1992) is used to search for the level of agreement between all four groups of respondents on all variables concerning strategic HRD aligning. If they fully agree, this coefficient is equal to 1 . All variance is then explained by differences between companies. If all respondents in a company fully disagree, the coefficient is equal to zero. Variance is then explained by differences between individual respondents. Based on the data in the last column of Table 5, it may be concluded that respondents do not agree very much concerning their opinion on all items of strategic HRD aligning. This is especially the case for kind and level of HRD goals and objectives formulated (with coefficient .02 and .03 respective).

\section{Differences Between Economic Sector and Type of HRD Program}

The data in Table 6 shows that strategic HRD aligning process in the case of social skills programs significant differs from automation programs in most perspectives.

Table 6: Differences in strategic HRD aligning for economic sector and type of HRD program

\begin{tabular}{|c|c|c|c|}
\hline & $\mathbf{N}$ & $\begin{array}{l}\text { type of HRD } \\
\text { program }{ }^{\text {a) }}\end{array}$ & $\begin{array}{l}\text { econ. } \\
\text { sector }^{\text {b) }}\end{array}$ \\
\hline number of stages in which was participated (maximum=2) & 767 & $.36^{* *}$ & -.01 \\
\hline number of categories of provided information (maximum $=10$ ) & 767 & $.39^{* *}$ & .24 \\
\hline number of levels of provided information (maximum=3) & 767 & $.21^{* *}$ & .05 \\
\hline number of consultative structures involved (maximum=4) & 767 & $.18^{* *}$ & .03 \\
\hline number of information gathering procedures applied $(\max =6)$ & 723 & $.22^{* *}$ & .06 \\
\hline number of types of HRD goals/objectives formulated $(\max =6)$ & 767 & .05 & .03 \\
\hline number of levels of HRD goals/objectives formulated ( $\max =3$ ) & 767 & -.01 & .02 \\
\hline number of aligning aspects (maximum $=4$ ) & 767 & $.40^{* *}$ & -.08 \\
\hline number of aligning levels (maximum=3) & 767 & $16^{* *}$ & .08 \\
\hline
\end{tabular}

a) difference between social skills programs compared to automation programs

b) difference between the financial and commercial services sector compared to the industrial sector

**) significant difference between social skills programs compared to automation programs at .05 level

No significant differences between the automation and social skills programs, however, were found concerning the kind and level of HRD goals and objectives. It looks as if the aligning processes in the case of social skills programs were more intensive than those of automation programs. This, however, did not result into the formulation of more kinds of HRD goals and objectives on various policy levels. As was expected, no significant differences are found for the economic sector.

\section{Conclusion and Discussion}

In order to answer the main research question regarding the level of vertical HRD policy integration, the survey investigated how strategic HRD aligning processes had taken place within the companies studied. Results indicate that HRD participants, their supervising managers and subordinates attach great interest to contributing to aligning processes (HRD representatives were not questioned in this perspective). It turned out, however, that their interests are insufficiently converted into real contributing activities. Findings indicate that, on average, the four groups of respondents were involved in less than one of the three stages of the aligning process. With the exception of HRD representatives, they provided information on less than one information category out of ten. Also scant participation in formal and informal consultative structures was found and minor use made of information gathering procedures. In most of the companies studied, no broad aligning process at strategic, tactical and operational levels was found. The aligning process was restricted to one organizational level, on average, mostly the operational one. This means that in most cases HRD goals and objectives were formulated concerning the skills, knowledge and attitudes that participants had to master at the end of the program. In this context, no differences were found between automation and social skills programs. Both programs, however, do vary on the three other aspects of the aligning process. Generally speaking the aligning process for social skills was somewhat more intensive than for automation programs. The four groups of stakeholders varied in their contribution towards the aligning process. This is mainly the case for the kind and level of HRD goals and objectives they planned to realise with the HRD programs. This 
impedes the reaching of 'strategic partnership', which is necessary for achieving strategically aligned HRD programs. It also impedes the achievement of consensus, or external consistency between all stakeholders on what the problem is, and how it will be resolved by targeted HRD programs or other learning interventions. External consistency is seen as the homogeneity of the notions of parties involved on what the problem is and how it can be solved by means of educational provisions'(Kessels, 1993, p. 27).

Based on the findings, the conclusion can be drawn that, in general, the HRD aligning process within the companies studied was not really strategic and hardly interactive. It is then problematical to harmonise HRD policy processes in a vertical direction. This kind of harmonization was hardly found in the companies studied. Many respondents were not involved in the aligning process. HRD participants, their supervising managers and subordinates seemed to have little idea of important data at strategic and tactical organization levels, which is needed to gain more insight into the problem and into related HRD needs. HRD goals and objectives are mainly formulated at the operational level, concerning knowledge, skills and attitudes of employees at the end of the HRD programs. Although the higher goal levels are not frequently mentioned, these goals are important to clarify the importance of the newly acquired competencies for the whole company.

The absence of vertical policy integration hinders the extent to which horizontal integration takes place. Horizontal integration means the harmonization of various kinds of policy (Leijten, 1992; Leget, 1997; Glaudé, 1997), in this case, the harmonization of HRD policies and the mission, policy and strategy of the organization as a whole. If the intended HRD goals and objectives within the organization are unclear, then it is problematical to arrive at strategically aligned HRD programs and activities. Therefore companies need to strive to involve all relevant stakeholders whenever possible and functional with the strategic HRD aligning process. The necessary information for problem solving needs to be gathered in formal and informal consultative structures at various policy levels, while different kinds of HRD goals and objectives at several policy levels should be formulated in order to achieve vertical policy integration. By focusing on these four aspects, the aligning process will result in more strategically aligned HRD programs and activities in which employees acquire the knowledge and skills needed for an organization now and in the future. Cooperation between respondents - strategic partnership - is also necessary in order to gain consensus on what the problem is and how it can be resolved. The HRD representatives need to play a key role as HRD consultants in all of this in order to support other stakeholders in the aligning process.

\section{References}

Banathy, B.H. (1991). Systems design of education. A journey to create the future. Englewood Cliffs: Educational Technology Publications.

Bryck, A.S., \& Raudenbush, S.W. (1992). Hierarchical Linear Models: Applications and Data Analysis Methods. Newbury Park: Sage Publications.

Garavan, T.N., Costine, P., \& Heraty, N. (1995). The emergence of strategic human development. Journal of European Industrial Training. 19 (10), 4-10.

Glaudé, M.Th. (1997). Werkplek-opleiden als innovatie. [Training and development on-the-job as innovation.] Dissertation University of Utrecht.

Goldstein, H., Rasbash, J., Plewis, I., Draper, D., Browne, W., Yang,, M., Woodhouse, G., \& Healy, M. (1998). A user's guide to MlwiN. London/Bath: University of London/University of Bath.

Heffen, O. van (1993). Beleidontwerpen en omgevingsfactoren: vier alternatieve strategieën [Policy design and environmental factors: four alterbative strategies]. In O.van Heffen \& M.J.W. Twist (Red.). Beleid en wetenschap. Hedendaagse bestuurskundige beschouwingen (pp. 67-81). Alphen aan den Rijn: Samsom H.D. Tjeenk Willink.

Kaufman, R. (1986). Assessing needs. Introduction to performance technology (vol.1) (pp. 25-50). Washington D.C.: The National Society for Performance and Instruction.

Kessels, J.W.M. (1993). Towards design standards for curriculum consistency in corporate education. Dissertation.Terschuur, the Netherlands.

Koopman, J., \& Pool, J. (1992). Management en besluitvorming in organisaties. Een strategisch perspectief [Management and decisionmaking in companies. A strategic perspective]. Assen/Maastricht: Van Gorcum.

Leget, J. (1997). Personeelbeleid en succes van organisaties. Resultaat gericht Human Resources Management in Nederland. Deventer: Kluwer Bedrijfsinformatie.

Leijten, A.T. (1992). Stimulerend personeelsmanagement. Een effectiviteitsdiagnose. Dissertation. University of Twente.

Mintzberg, H. (1994). The Rise and Fall of Strategic Planning. New York: Prentice Hall. 
Mulder, M., Akkerman, J.S., \& Bentvelsen, N. (1989). Bedrijfsopleidingen in Nederland [Corporate training and development in the Netherlands]. The Hague: Institute for Educational Research.

Robinson, D.G.. \& Robinson, J.C. (1989). Training for impact. How to link training to business needs and measure the results. San Francisco/London: Jossey-Bass Publishers.

Romiszowski, A.J. (1984). Designing instructional systems: decisionmaking in course planning and curriculum design. London: Kogan Page.

Rothwell, W.J., \& Kazenas, H.C. (1989). Strategic Human Resource Development. Englewood Cliffs/New Yersey: Prentice Hall.

Rummler, G.A., \& Brache, A.P. (1995). Improving performance. How to manage the white space on the organizational chart. San Francisco: Jossey-Bass Publishers.

Swanson, R.A. (1994). Analysis for improving performance. Tools for diagnosing organizations \& documenting workplace expertise. San Francisco: Berett-Koehler.

Tjepkema, S., \& Wognum, A.A.M. (1999). Human Resource Development in a Corporate Setting from an Organizational Point of View. In: A.J. Visscher (red.), Managing schools towards high performance.Lisse: Swets \& Zeitlinger. pp. 245-287.

Torraco, R. (1995). HRD alignment: A systemic assessment of HRD in organizations. In E.F. Holton III (Ed.), AHRD Conference Proceedings, St. Louis: AHRD 12-1.

Ven, A. van de, \& Drazin, R. (1985). The concept of fit in contingency theory. Research in Organizational Behavior, 7, 333-365.

Wognum, A.A.M. (1998). HRD Policymaking in Companies: an Interpretation of the Differences. Human Resource Development Quarterly, 9(3), 255-269.

Wognum, A.A.M. (1999). Strategische afstemming en de effectiviteit van bedrijfsopleidingen. [Strategic HRD Aligning and HRD Effectiveness]. Dissertation. Enschede: Twente University Press. 